\title{
Electron microscopic and spectroscopic analysis of airborne ultrafine particles: its effects on the cell viability
}

\author{
Jeong Bin Yang ${ }^{1 \dagger}$, Hyung Joong Yun ${ }^{2 \dagger}$, Min Jeong Yeon ${ }^{1}$, Dooil Jeoung ${ }^{1}$, Kyoung-nam Jo ${ }^{3,4^{*}}$ and Hyun Suk Jung ${ }^{\text {* }^{*}}$
}

\begin{abstract}
Particulate matter (PM) is one of the most common air pollution sources causing various health-related conditions like cardiovascular diseases. However, among the three major PM types, UFPs have not yet been independently studied for their toxic effects on human health. In this study, we collected airborne dusts from Chuncheon-si, Republic of Korea, and analyzed it to understand the structural and chemical features of UFPs by using transmission electron microscope (TEM), energy-dispersive X-ray spectroscopy (EDX), and X-ray photoelectron spectroscopy (XPS). The TEM result showed UFP size to be within $100 \mathrm{~nm}$, with some even appearing about $10 \mathrm{~nm}$ in size, while the $X$ ray spectroscopic studies implied the presence of sulfur to be a part of the UFPs chemical composition. We extended our study by carrying out in vitro cell analysis to understand the cellular response upon UFPs treatment. Our results serve as an analytical platform providing the preliminary information about the structural and compositional aspects of UFPs that can be attributed to further understanding of sulfur-induced human diseases.
\end{abstract}

Keywords: Particulate matter, Ultrafine particle, Cardiovascular diseases, TEM, EDX, XPS

\section{Introduction}

Particulate matter (PM) are categorized as very fine particles (less than $10 \mu \mathrm{m}$ in diameter) which cannot be perceived by the naked eyes. Recently, it is recognized as one of the major health-related air pollution sources (Piao et al. 2018; Samet et al. 2000). PM is classified into three types according to its particle size, i.e., PM10 (less than $10 \mu \mathrm{m}$ in diameter), PM2.5 (FP, less than $2.5 \mu \mathrm{m}$ in diameter) and ultrafine particles (UFPs, less than 100 $\mathrm{nm}$ in diameter) (Brook et al. 2004). PM is found to circulate throughout the respiratory system and is therefore associated with increased respiratory, cardiovascular, and cardiopulmonary disease-related morbidity and mortality (Lee et al. 2018; Oberdorster et al. 2004; Pope et al.

\footnotetext{
* Correspondence: kjo@kangwon.ac.kr; hsjung@kangwon.ac.kr

${ }^{\dagger}$ Jeong Bin Yang and Hyung Joong Yun contributed equally to this work.

${ }^{3}$ Division of Geology and Geophysics, College of Natural Sciences, Kangwon National University, Chuncheon 24341, Republic of Korea

'Department of Biochemistry, College of Natural Sciences, Kangwon National University, Chuncheon 24341, Republic of Korea

Full list of author information is available at the end of the article
}

2004). Short-term exposure to PM (for several minutes to several hours) can not only trigger myocardial infarction but also cardiac ischemia, arrhythmias, stroke, heart failure as well as lung cancer. More long-term exposure may also increase the possibility of acquiring chronic cardiovascular diseases (Brook 2008; Ren et al. 2017).

The toxicity of PM is correlated with the size of its particle where smaller the particle, more harmful is its impact on the body (Dockery et al. 1993). Therefore, UFPs which are the smallest in size are expected to have the largest adversity on human health. IARC (International Agency for Research on Cancer), which is an affiliated organization of WHO (World Health Organization), has designated PM to be a carcinogenic air pollutant. Thus, PM causes severe environmental issues for human health. In addition, the Asian Dust, which is known to contain air pollutants such as PM has been found beyond the heavily industrialized zone in China reaching the country of Republic of Korea. Consequently, some of the PM components found in Republic of
Springer Open (c) The Author(s). 2020 Open Access This article is licensed under a Creative Commons Attribution 4.0 International License, which permits use, sharing, adaptation, distribution and reproduction in any medium or format, as long as you give appropriate credit to the original author(s) and the source, provide a link to the Creative Commons licence, and indicate if changes were made. The images or other third party material in this article are included in the article's Creative Commons licence, unless indicated otherwise in a credit line to the material. If material is not included in the article's Creative Commons licence and your intended use is not permitted by statutory regulation or exceeds the permitted use, you will need to obtain permission directly from the copyright holder. To view a copy of this licence, visit http://creativecommons.org/licenses/by/4.0/. 
Korea appear to be derived from the industrial emissions transported by the Asian dust (Park and Dam 2008).

PM is mainly generated by the combustion of fossil fuels such as natural gas and diesel fuel (i.e., automobile fuel, heating, industry) (Holmén and Ayala 2002; Murphy et al. 2009; Rogge et al. 1993; Xue et al. 2018). It is comprised of metallic elements (As, $\mathrm{Be}, \mathrm{Ca}, \mathrm{Cd}, \mathrm{Co}$, $\mathrm{Cr}, \mathrm{Fe}, \mathrm{K}, \mathrm{Mn}, \mathrm{Ni}, \mathrm{Pb}, \mathrm{Sb}, \mathrm{Se}, \mathrm{Zn}$ ) (Park and Dam 2008), carbon sources (Adams et al. 2015; Funasaka et al. 2000), and inorganic compounds such as sulfate, nitrate, halide, and ammonium (Borgie et al. 2015; Brewer et al. 2015). Among them, carbon and sulfur sources are found to be highly correlated with cardiovascular diseases (Adams et al. 2015; Brook 2008; Lee et al. 2005).

Most of the sulfur-containing substances (sulfate, sulfoxides) are found under $\mathrm{PM}_{2.5}$ level category, where the UFPs contain more amount of sulfur than the former (Adams et al. 2015; Funasaka et al. 2000; Wei et al. 2018). On a global level, a lot of research reported that the increase of $\mathrm{SO}_{2}$ pollution is highly correlated with mortality and morbidity of cardiovascular diseases statistically (Sunyer et al. 2003; Tran et al. 2019; Yang and Liu 2019). In addition, systemic abnormalities caused by $\mathrm{SO}_{2}$ such as rise in the blood pressure, inflammation, and thrombosis provide a plausibility of these being interrelated with sulfur (Delfino et al. 2005; Ren et al. 2017; Tran et al. 2019).
Here, we investigated UFPs which have not been studied much in comparison to other PM types partly because of its extremely small size. In general, the extent of the study of PM has been limited only to $\mathrm{PM}_{2.5}$ level and very little is known about the much smaller, UFPs. Thus, we analyzed the structural and chemical composition of UFPs by using TEM, XPS, and EDX creating a platform to derive a better structural and conformational aspect of the UFPs.

\section{Materials and methods}

\section{Preparation of the particulate matter}

Since the probability of the Asian dust occurrence is maximum during the early summer period in Republic of Korea, particulate matter analyzed in this study was collected during this period. From that, days having the most conducive weather conditions and relatively higher occasion of PM2.5 incidences were taken into consideration. This particulate matter was collected twice on a petri dish for $24 \mathrm{~h}$ from the natural atmosphere at the height of $20 \mathrm{~m}$ from the ground level to avoid any obvious or deliberate artificial effect caused by drastic variables to maintain a constant condition during the sampling (Fig. 1). The obtained particulate matter was dissolved in 100\% ethanol and stored in $1.5 \mathrm{ml}$ Eppendorf tube. This was then centrifuged at $5000 \mathrm{rpm}$ for $5 \mathrm{~min}$ to collect the "large particles" as a pellet. Note that the supernatant contained the "ultrafine particles" while the pellet contained PM10 and PM2.5 respectively.

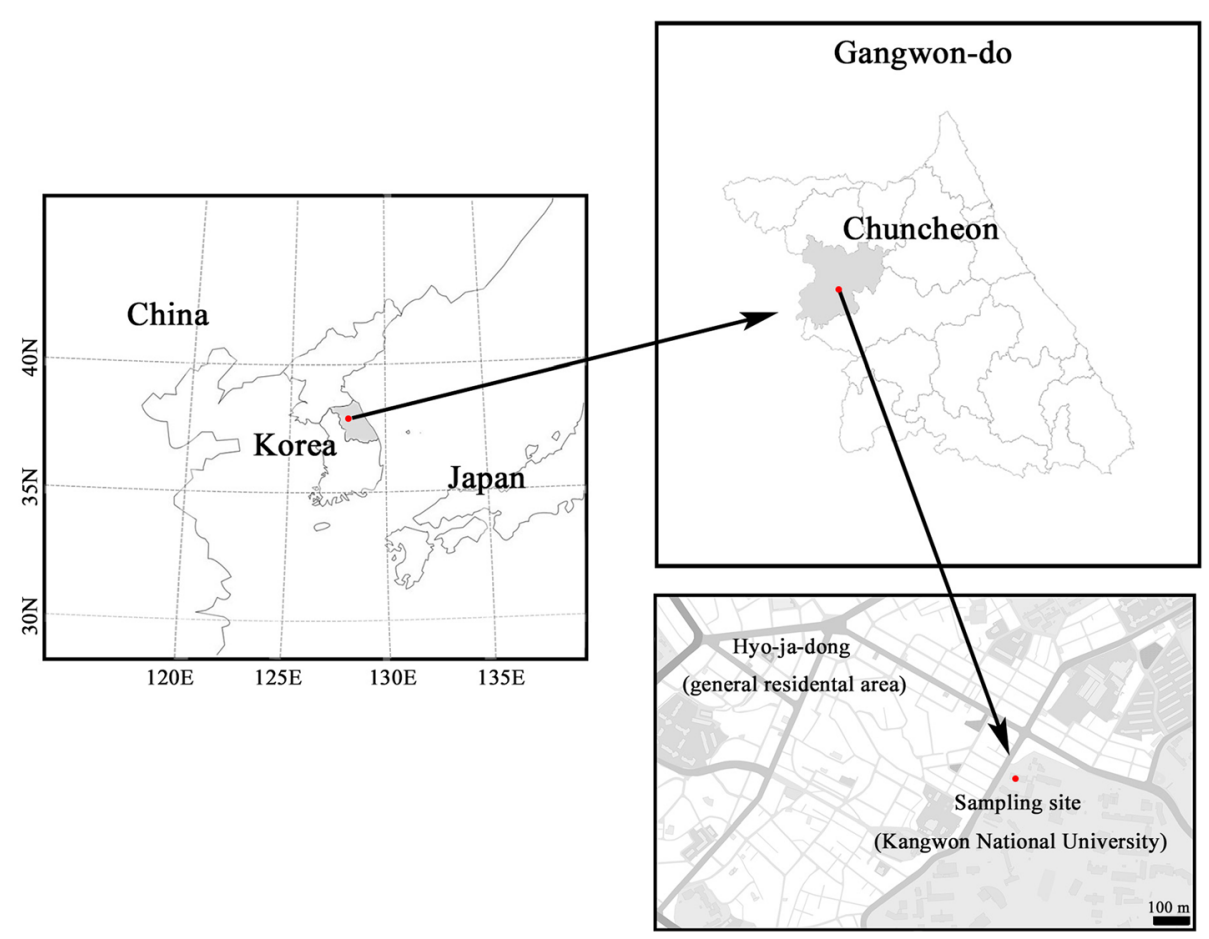

Fig. 1 Location of particulate matter collected in Republic of Korea. Particulate matter (PM) of this study was collected from Hyo-ja-dong

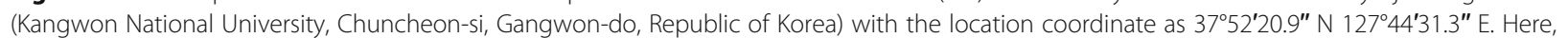
Hyo-ja-dong area is shown as a general residential area in the university premises. Scale bar: $100 \mathrm{~m}$ 


\section{Transmission electron microscopy}

We collected the PM from ambient circumstances and segregated the "whole particles" respectively to "large particles" (PM10 and PM2.5) and "UFPs" by centrifugation. The "large particles" were deposited as pellet while the UFPs remained in the supernatant itself. The supernatant containing UFPs was then visualized by transmission electron microscopy (TEM). $5 \mu \mathrm{l}$ of the sample was directly applied to a carbon-coated grid without any staining process, and the grid was examined using Technai 10 (FEI, U.S) TEM operated at $100 \mathrm{kV}$. Images were then recorded on an UltraScan 1000 CCD camera (Gatan, USA) at a magnification of $\times 17,000(0.62 \mathrm{~nm} /$ pixel $)$. Instrumentation was used in Kangwon Center for Systems Imaging.

\section{X-ray photoelectron spectroscopy and energy-dispersive $X$-ray spectroscopy}

"Whole particles" include ultrafine particles whereas the "large particles" contained all other particles except the UFPs. Each set of the particle was dried to a powdered form and loaded onto an X-ray photoelectron spectroscopy
(XPS) and energy-dispersive X-ray spectroscopy (EDX) which was performed at Korea Basic Science Institute (KBSI), Daejeon, Republic of Korea. X-ray photoelectron spectroscopy (XPS) (SUPRA, Kratos. Inc.) with monochro-

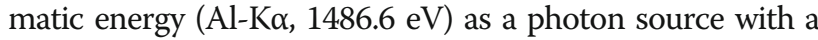
hemispherical analyzer was employed to investigate the surface elements in the sample. The resolution of electron analyzer was $0.47 \mathrm{eV}$ as measured from the full width at half maximum (FWHM) of the $\mathrm{Ag} 3 \mathrm{~d} 5 / 2$ peak. The binding energy of XPS spectra were calibrated by the position of C $1 \mathrm{~s}(285.0 \mathrm{eV})$ of adventitious carbons in the air. Highresolution XPS spectra were obtained using an analysis area of $400 \mu \mathrm{m}$ of the $40 \mathrm{eV}$ pass energy. The surface morphological and microstructural analysis was studied using field emission scanning electron microscopy (FE-SEM, Hitachi S4800) equipped with an energy-dispersive X-ray (EDX)

\section{Cell culture}

Human non-small cell lung cancer cell line PC-9 was provided by L-Base Company, Seoul, Republic of Korea, and cultured in Dulbecco's modified minimal

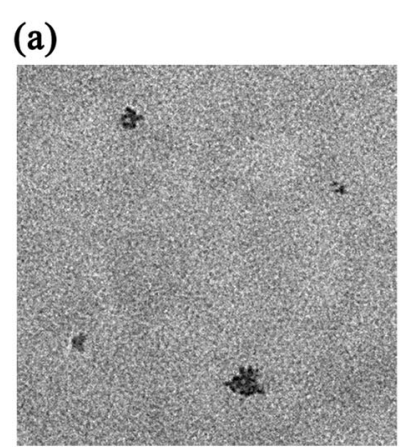

(b)

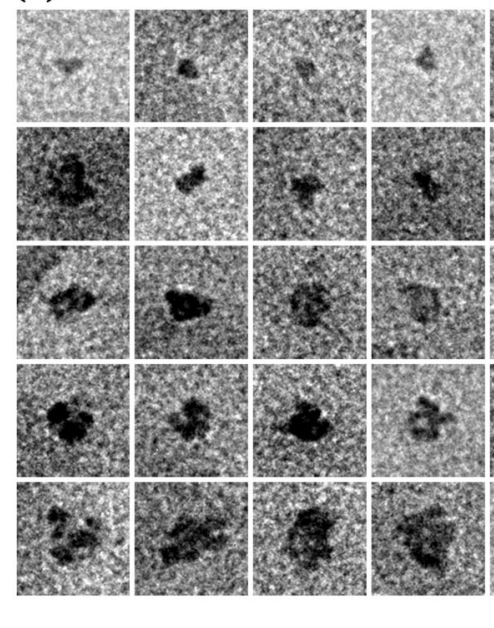

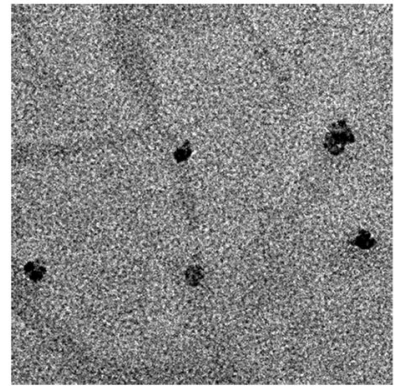

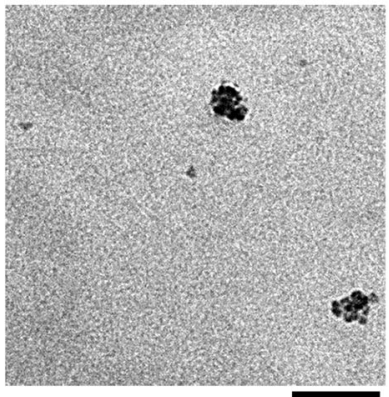

$100 \mathrm{~nm}$

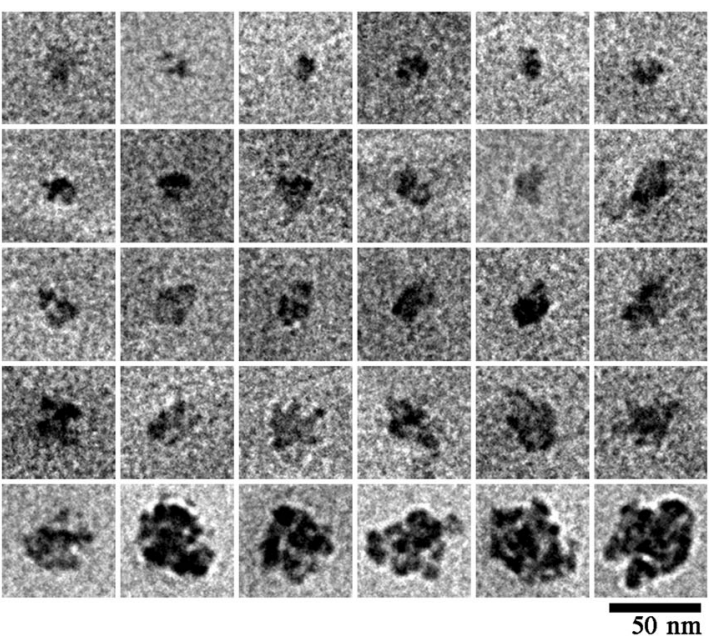

Fig. 2 Transmission electron microscopic analysis of ultrafine particles (UFPs). a, b Non-stained transmission electron microscopy (TEM) images of ultrafine particles and its particle set showed general appearances of ultrafine particle; images showed the presence of various size and shaped particles. Collected ultrafine particle set showed the smallest particle was $9 \times 13 \mathrm{~nm}$ in length and width (left top) while the largest sized particle was $52 \times 53 \mathrm{~nm}$ in length and width (right bottom). Majority of the particles appeared to have diameter smaller than $50 \mathrm{~nm}$. Scale bars: a $100 \mathrm{~nm}, \mathbf{b} 50 \mathrm{~nm}$ 
essential medium (Corning) supplemented with heatinactivated $10 \%$ fetal bovine serum (Serana) and antibiotics at $37^{\circ} \mathrm{C}$ in a humidified incubator with a mixture of $95 \%$ air and 5\% CO2. For cell viability assay, cells were directly counted in a hemocytometer after $0.2 \%$ trypan blue (Lonza) staining.

\section{Live cell imaging and cell viability assay}

Cells were seeded at $5 \times 10^{4}$ cells per well in 96-well plate (SPL) and allowed to adhere for $24 \mathrm{~h}$. Two-fold serial dilutions $(25-100 \mu \mathrm{g} / \mathrm{ml})$ of the UFP samples were dissolved in DMEM medium containing 10\% fetal bovine serum and $1 \%$ penicillin. Subsequently, UFP solutions were treated to the cells $(100 \mu \mathrm{l} /$ well $)$ for $48 \mathrm{~h}$. During experiment, the plate was inserted into the IncuCyteTM (Sartorius) for real-time imaging of live cells and imaged per well under $\times 10$ magnification every $2 \mathrm{~h}$ for a total of $48 \mathrm{~h}$. Data were analyzed using the IncuCyte Confluence version 1.5 software (Sartorius), which quantified cell surface area coverage as confluence values. After $48 \mathrm{~h}$ of treatment, the cells were used in the MTT assay to determine cell viability. The cells were maintained in the culture medium containing $500 \mu \mathrm{g} / \mathrm{ml}$ MT'T (Duchefa) for $2 \mathrm{~h}$. The formazan dye was dissolved with dimethyl sulfoxide, and its concentration was determined by measuring the absorbance at $570 \mathrm{~nm}$.

\section{Results and discussion}

Visualizing the structural appearance of UFPs

As mentioned earlier, PM has a diversity in its particle size distribution where the smallest-sized particle UFPs being critically harmful have not been explored in the structural aspect. Thus, we designed an experimental scheme to characterize them by TEM. From TEM imaging, we detected clusters of nano-sized particles. Their diameters being smaller than $100 \mathrm{~nm}$ are regarded to be UFPs (Fig. 2a). Thus, we grouped each UFP particle and constructed a collective set for standardization and analyzed its structural features (Fig. 2b). UFPs mostly showed irregular angular or aggregated characteristics in their overall shape. The collected UFPs appear to be extremely small in size ranging from $53 \mathrm{~nm}$ to $9 \mathrm{~nm}$.

\section{Analysis of the chemical properties of UFPs}

After deriving the structural appearances of the UFPs by TEM, we then moved on to analyze the chemical composition of UFP to investigate if they contained any element known to be harmful to human health by using XPS and EDX. UFPs mainly share the same chemical elements as that with PM10 and PM2.5 sources and further analysis of XPS for 10 elements (a)

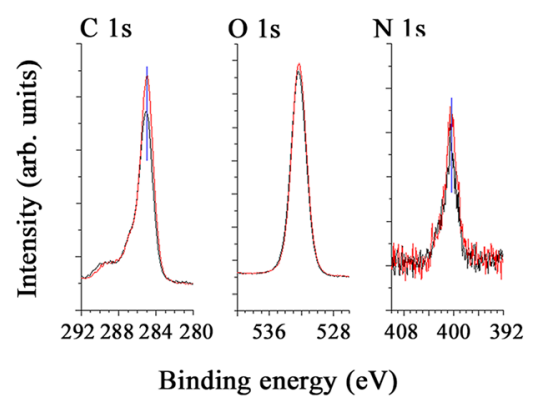

(c)

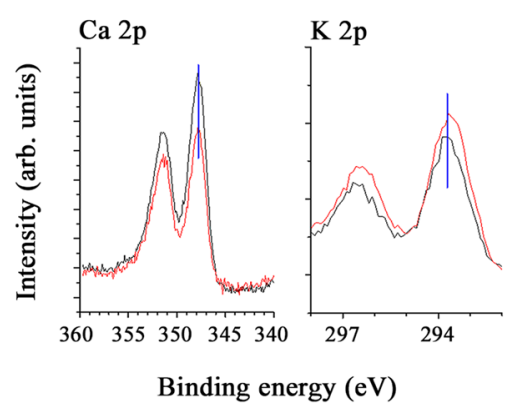

(b)

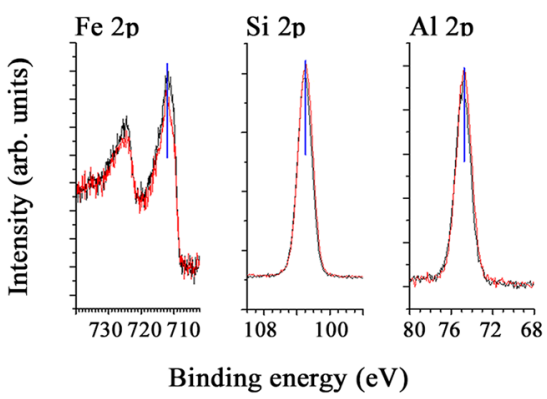

(d)

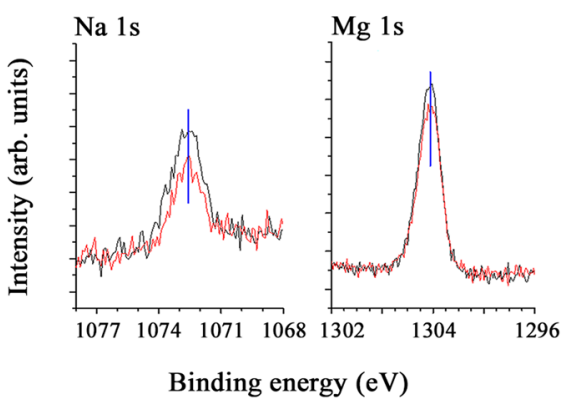

Fig. 3 X-ray photoelectron spectroscopy analysis comparing the "whole particles" with "large particles". a-d Chemical composition analyzed by Xray photoelectron spectroscopy (XPS): black profile, "whole particles"; red profile, "large particles." Analysis was done to detect: carbon, oxygen, and nitrogen (a); iron, silicon, and aluminum (b); calcium and potassium (c); sodium and magnesium (d). Note that these representative results were taken from the data of five independent XPS analysis with three independent preparations of UFPS 
(C, O, N, Fe, Si, $\mathrm{Al}, \mathrm{Ca}, \mathrm{K}, \mathrm{Na}$, and $\mathrm{Mg}$ ) did not show any significant difference between the whole particles and large particles (Fig. 3). However, EDX assay conducted to analyze the detailed differences in the chemical composition showed the whole particles to specifically contain sulfur (Fig. 4). It can thus be said that UFPs and not large particles are the ones that contain sulfur solely. This inference can be supported by the replicated results for both particles.

\section{In vitro cytotoxicity analysis of UFPs}

Since the lungs are directly exposed from UFPs through respiration, we assessed in vitro cytotoxicity analysis using live cell imaging with PC-9 which is well known as a human lung adenocarcinoma cell line. During incubation, untreated control cells grew consistently while the UFP treated groups of different concentrations showed decreased cell confluency as UFPs dosage increased (Fig. 3a, b). Furthermore, we assessed MTT assay to determine cell viability at the end point of incubation where 25 and $50 \mu \mathrm{g} / \mathrm{ml}$ UFPs dosed classes declined up to 26 and $28 \%$ in their cell viabilities respectively. Especially, $100 \mu \mathrm{g} / \mathrm{ml}$ of UFPs treated test which is the highest exposure group displayed a remarkable decrease in cell viability as much as 96\% (Fig. 3c). Cell confluency and viability showed a consistent outcome, thus indicating that UFPs from natural atmosphere have cytotoxic effect on the human lungs.

UFPs have been known to possess different composition based on different factors such as location and habitat environmental conditions (Dockery et al. 1993; Park and Dam 2008; Samet et al. 2000). We have collected UFPs from a general residential area in Chuncheon, Republic of Korea, to symbolize a typical city ambience and analyzed their structural and chemical properties by using TEM, XPS, and EDX. Here, we successfully demonstrated UFPs by TEM which showed many erratic forms and were uneven, angular and highly variable in shape. Although an accurate mechanism of UFPs affecting humans is unclear, in virtue of these structural characteristics such as hypervariable surface and a size small enough to permeate cells can provide a reliable evidence that UFPs are especially pernicious to living organisms. From such distinctive property of UFPs, it is able to penetrate via the respiratorycardiovascular system facilitating invasion to any part of the organism and thereby affecting them (Dockery et al. 1993; Venners et al. 2003). Chemical composition of UFPs through XPS offered identical results for whole

(a)
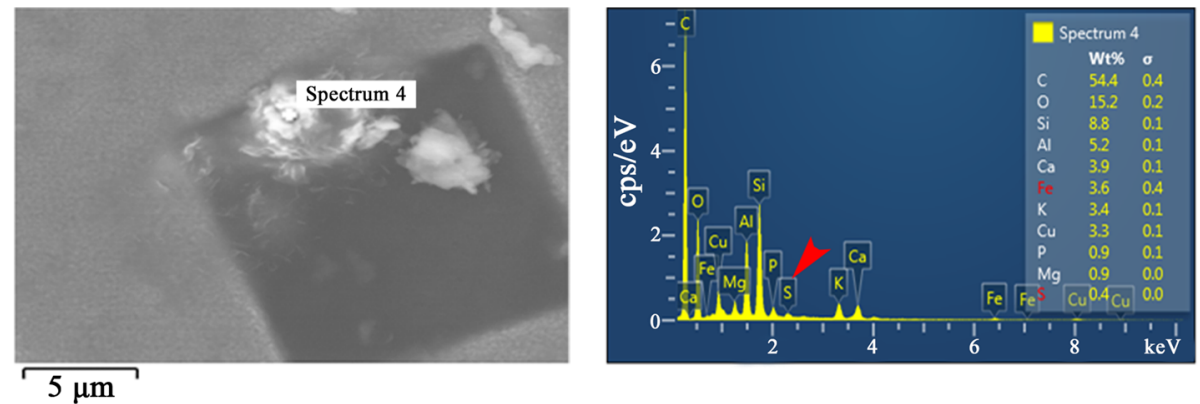

(b)
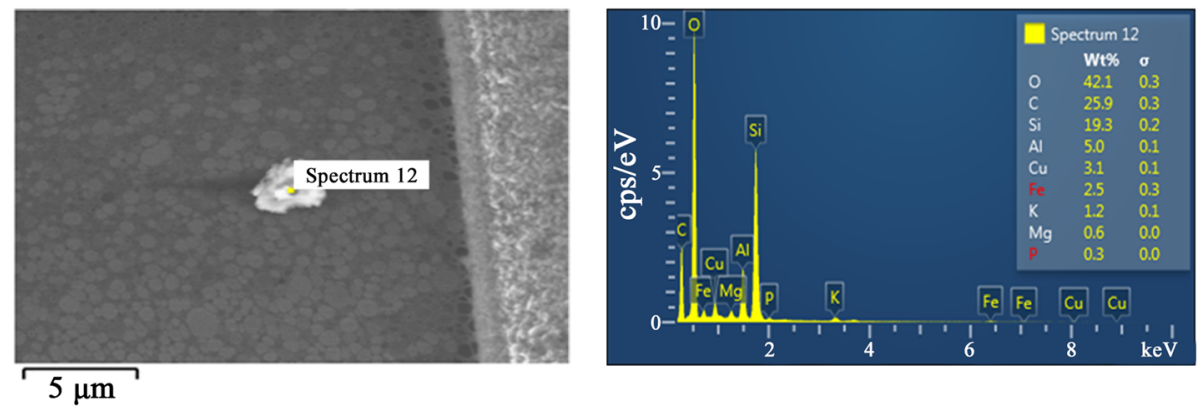

Fig. 4 Energy-dispersive X-ray spectroscopy profiles between twhole particlesofiles large particleso. a, b Scanning electron microscopic images (left panels) showing the "whole particle" and "large particle," indicated by the spectrum 4 and 12 (spectrum numbers refer to the characteristic location of the analyzed point), respectively, and their respective atomic compositions analyzed by energy-dispersive X-ray spectroscopy (right panels). For the energy-dispersive X-ray spectroscopy (EDX) profile of "whole particles" and "large particles" (right panels), each peak represents a different chemical element and specially sulfur element (red arrow) was detected in the "whole particles." Note that these representative results were taken from the data of five independent EDX analysis with three independent preparations of UFPs. Scale bars: a $5 \mu \mathrm{m}$, $\mathbf{b} 5 \mu \mathrm{m}$ 
particles and large particles but EDX in particular, depicted only UFPs to possess the sulfur element. In totality, sulfur accounted for only a small amount of the elements detected by EDX. Although the amount of sulfur detected is small, they have a significant relevance since they form a part of the UFPs which themselves occupy a very small part of the whole particles. Our technical demonstration by EDX and XPS provides a reliable evidence of UFPs to be linked with sulfur justifying the objective mentioned in the previous studies (Borgie et al. 2015; Brook et al. 2004; Zhu et al. 2019).

It can thus be said that the structural and chemical properties of UFPs having unique biochemical effect compared to other PM types are importantly associated with cardiovascular diseases (Gong et al. 2014). Thus, in this study, we strived to derive the basic characteristics of UFPs by using tools like TEM and EDX. In addition, most PM and sulfur related researches are restricted only up to PM2.5 level and not smaller than that like the UFPs (Sunyer et al. 2003; Tran et al. 2019; Venners et al. 2003; Yang and Liu 2019; Zhu et al. 2019). Nevertheless, we have reported the structural and chemical analysis of PM particles beyond PM2.5, particularly the UFPs. Consequently, we demonstrated the UFPs to possess sulfur, implying their possible potential in the toxicity of UFPs.

As an auxiliary study, in vitro assay by using live cell imaging and MTT assay determining the cell viability displayed significant role of the UFPs in understanding the lung cellular response. To data, we demonstrated that UFPs have a considerable cytotoxic effect on human lung adenocarcinoma cell line, PC9 (Fig. 5). This can serve to become a strong evidence to support our proposition about the critical toxicity of UFPs similar with other investigation (Steenhof et al. 2011). Surprisingly, all the groups of cells treated with UFPs demonstrated a noticeable decline in the cell viability, especially $100 \mu \mathrm{g} /$ $\mathrm{ml}$ dosage showing the most outstanding severe effect on the PC 9 cells. Thus, there was a significant correlation between the concentration of UFPs and MTT cell viability of PC 9 cells.

In summary, the smallest PM, UFPs known to cause the strongest effect on human beings contains sulfur

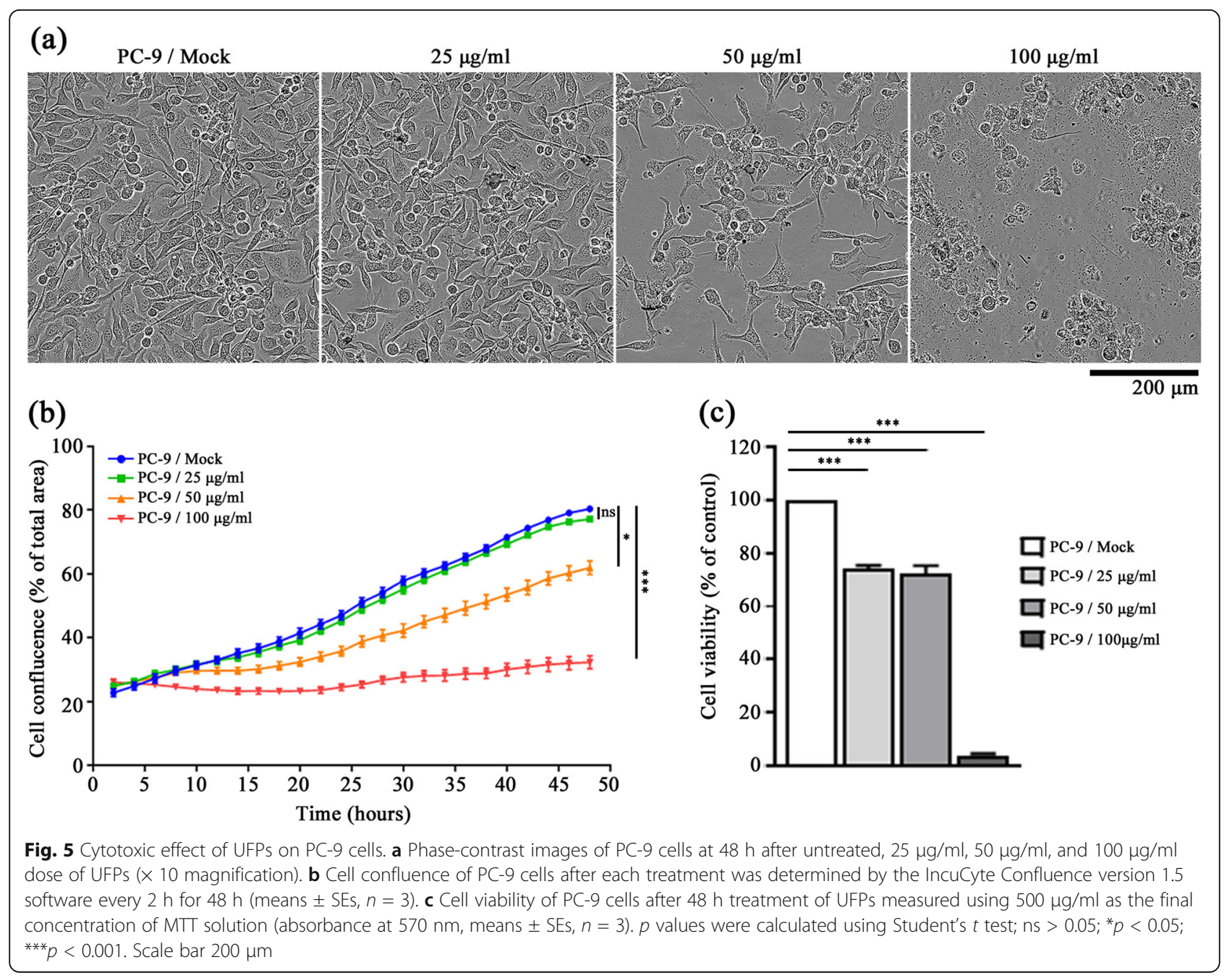


specifically. Thus, we presume that their harmful mechanisms are correlated with not only their nano-sized vascular permeability but also chemical composition containing sulfur. Until now, most of the research work has focused on understanding the sulfur induced mortality of cardiovascular diseases; however, they are limited to PM2.5 level. This work can serve as a structural base with straightforward manner to approach UFPs for carrying out further studies exploring the detrimental aspects of UFPs which can help to develop better emission regulations pertaining to the presence of UFPs in the near future.

\section{Abbreviations}

TEM: Transmission electron microscope; EDX: Energy-dispersive X-ray spectroscopy; XPS: X-ray photoelectron spectroscopy; FP: Fine particulate matter; UFP: Ultrafine particle; PM: Particulate matter; MTT: 3-(4,5-dimethylthiazol-2yl)-2,5-diphenyltetrazolium bromide

\section{Acknowledgements}

Not applicable in this section.

\section{Authors' contributions}

J.B.Y. performed the preparation of PM, EM experiments, interpreted all obtained results, and was a major contributor in writing the paper. M.J.Y. performed live cell imaging, MTT assay and wrote the MTT assay part of the paper. H.J.Y. performed EDX and XPS experiments, and wrote method part of EDX and XPS. K.N.J. performed the editing of paper to add geological logic. D.I.J. supervised the live cell imaging and MTT assay part. H.S.J. supervised the whole project and wrote the paper. All authors read and approved the final manuscript.

\section{Funding}

This work was supported by 2018 Research Grant (PoINT) from Kangwon National University and grants from the Basic Science Research Program through the National Research Foundation of Korea funded by the Ministry of Science, ICT and Future Planning (2017M3A9G7072417 to Dooil Jeoung, $2018 R 1 D 1 A 1 B 07045580$ to H.S. Jung), the Korea Basic Science Institute (KBSI), National Research Facilities \& Equipment Center (NFEC), grant funded by the Korea government (Ministry of Education) (2019R1A6C1010006), and the Next-Generation BioGreen Program (SSAC, PJ013273042018 to H.S. Jung).

\section{Availability of data and materials}

All data generated or analyzed during this study are included in this article and no datasets were generated or analyzed during the current study

\section{Competing interests}

No potential competing interest relevant to this article was reported.

\section{Author details}

'Department of Biochemistry, College of Natural Sciences, Kangwon National University, Chuncheon 24341, Republic of Korea. ${ }^{2}$ Research Center for Materials and Analysis, Korea Basic Science Institute, 169-148 Gwahak-ro, Daejeon 34133, Republic of Korea. ${ }^{3}$ Division of Geology and Geophysics, College of Natural Sciences, Kangwon National University, Chuncheon 24341, Republic of Korea. ${ }^{4}$ Critical zone Frontier Research Laboratory (CFRL), Kangwon National University, Chuncheon 24341, Republic of Korea.

Received: 4 June 2020 Accepted: 29 July 2020

Published online: 08 August 2020

\section{References}

Adams K, Greenbaum DS, Shaikh R, van Erp AM, Russell AG. Particulate matter components, sources, and health: Systematic approaches to testing effects. J Air Waste Manage Assoc. 2015;65:544-8.

Borgie M, Dagher Z, Ledoux F, Verdin A, Cazier F, Martin P, Hachimi A, Shirali P, Greige-Gerges H, Courcot D. Comparison between ultrafine and fine particulate matter collected in Lebanon: chemical characterization, in vitro cytotoxic effects and metabolizing enzymes gene expression in human bronchial epithelial cells. Environ Pollut. 2015;205:250-60.

Brewer E, Li Y, Finken B, Quartucy G, Muzio L, Baez A, Garibay M, Jung H (2015) PM2.5 and ultrafine particulate matter emissions from natural gas-fired turbine for power generation. Atmos Environ 131:.

Brook RD. Cardiovascular effects of air pollution. Clin Sci. 2008;115:175-87.

Brook RD, Franklin B, Cascio W, Hong Y, Howard G, Lipsett M, Luepker R, Mittleman M, Samet J, Smith SC, Tager I. Air pollution and cardiovascular disease. Circulation. 2004;109:2655-71.

Delfino RJ, Sioutas C, Malik S. Potential role of ultrafine particles in associations between airborne particle mass and cardiovascular health. Environ Health Perspect. 2005;113:934-46.

Dockery DW, Pope CA 3rd, Xu X, Spengler JD, Ware JH, Fay ME, Ferris BG Jr, Speizer FE. An association between air pollution and mortality in six U.S. cities. N Engl J Med. 1993:329:1753-9.

Funasaka K, Miyazaki T, Tsuruho K, Tamura K, Mizuno T, Kuroda K. Relationship. between indoor and outdoor carbonaceous particulates in roadside households. Environ Pollut. 2000;110:127-34.

Gong J, Zhu T, Kipen H, Wang G, Hu M, Guo Q, Ohman-Strickland P, Lu SE, Wang Y, Zhu P, Rich DQ, Huang W, Zhang J. Comparisons of ultrafine and fine particles in their associations with biomarkers reflecting physiological pathways. Environ Sci Technol. 2014;48:5264-73.

Holmén BA, Ayala A. Ultrafine PM emissions from natural gas, oxidation-catalyst diesel, and particle-trap diesel heavy-duty transit buses. Environ Sci Technol. 2002;36:5041-50.

Lee B-K, Smith TJ, Garshick E, Natkin J, Reaser P, Lane K, Lee HK. Exposure of trucking company workers to particulate matter during the winter. Chemosphere. 2005;61:1677-90.

Lee CH, Shim HE, Song L, Moon HG, Lee K, Yang JE, Song HY, Choi YJ, Choi DS, Jeon J. Efficient and stable radiolabeling of polycyclic aromatic hydrocarbon assemblies: in vivo imaging of diesel exhaust particulates in mice. Chem Commun. 2018:55:447-50.

Murphy SM, Agrawal H, Sorooshian A, Padró LT, Gates H, Hersey S, Welch WA, Jung H, Miller JW, Cocker DR, Nenes A, Jonsson HH, Flagan RC, Seinfeld JH. Comprehensive simultaneous shipboard and airborne characterization of exhaust from a modern container ship at sea. Environ Sci Technol. 2009:43: 4626-40.

Oberdorster G, Sharp Z, Atudorei V, Elder A, Gelein R, Kreyling W, Cox C. Translocation of inhaled ultrafine particles to the brain. Inhal Toxicol. 2004;16: 437-45.

Park K, Dam HD. Characterization of metal aerosols in PM10 from urban, industrial, and Asian Dust sources. J Environ Monit. 2008;160:289-300.

Piao MJ, Ahn MJ, Kang KA, Ryu YS, Hyun YJ, Shilnikova K, Zhen AX, Jeong JW, Choi YH, Kang HK, Koh YS, Hyun JW. Particulate matter 2.5 damages skin cells by inducing oxidative stress, subcellular organelle dysfunction, and apoptosis. Arch Toxicol. 2018;92:2077-91.

Pope C, T. Burnett R, Thurston G, Thun M, E Calle E, Krewski D, Godleski J. Cardiovascular Mortality and Long-Term Exposure to Particulate Air Pollution Epidemiological Evidence of General Pathophysiological Pathways of Disease. Circulation. 2004;109:71-7.

Ren M, Li N, Wang Z, Liu Y, Chen X, Chu Y, Li X, Zhu Z, Tian L, Xiang H. The shortterm effects of air pollutants on respiratory disease mortality in Wuhan, China: comparison of time-series and case-crossover analyses. Sci Rep. 2017;7:40482.

Rogge WF, Hildemann LM, Mazurek MA, Cass GR, Simoneit BRT. Sources of fine organic aerosol. 5. Natural gas home appliances. Environ Sci Technol. 1993; 27:2736-44.

Samet JM, Dominici F, Curriero FC, Coursac I, Zeger SL. Fine particulate air pollution and mortality in 20 U.S. cities, 1987-1994. N Engl J Med. 2000;343: 1742-9.

Steenhof M, Gosens I, Strak M, Godri KJ, Hoek G, Cassee FR, Mudway IS, Kelly FJ, Harrison RM, Lebret E, Brunekreef B, Janssen NAH, Pieters RHH. In vitro toxicity of particulate matter (PM) collected at different sites in the Netherlands is associated with PM composition, size fraction and oxidative potential—-the RAPTES project. Part Fibre Toxicol. 2011;8:26-41.

Sunyer J, Ballester F, Tertre AL, Atkinson R, Ayres JG, Forastiere F, Forsberg B, Vonk JM, Bisanti L, Tenías JM, Medina S, Schwartz J, Katsouyanni K. The association of daily sulfur dioxide air pollution levels with hospital admissions for cardiovascular diseases in Europe (The Aphea-II study). Eur Heart J. 2003;24:752-60.

Tran B-L, Chang C-C, Hsu C-S, Chen C-C, Tseng W-C, Hsu S-H. Threshold Effects of PM2.5 exposure on particle-related mortality in China. Int J Environ Res Public Health. 2019;16:3549. 
Venners SA, Wang B, Xu Z, Schlatter Y, Wang L, Xu X. Particulate matter, sulfur dioxide, and daily mortality in Chongqing, China. Environ Health Perspect. 2003;111:562-7.

Wei L, Yue S, Zhao W, Yang W, Zhang Y, Ren L, Han X, Guo Q, Sun Y, Wang Z, Fu $P$. Stable sulfur isotope ratios and chemical compositions of fine aerosols (PM2.5) in Beijing, China. Sci Total Environ. 2018;633:1156-64.

Xue J, Li Y, Peppers J, Wan C, Kado NY, Green PG, Young TM, Kleeman MJ. Ultrafine particle emissions from natural gas, biogas, and biomethane combustion. Environ Sci Technol. 2018;52:13619-28.

Yang T, Liu W. Health effects of energy intensive sectors and the potential health co-benefits of a low carbon industrial transition in China. Int J Environ Res Public Health. 2019;16:3022.

Zhu F, Ding R, Lei R, Cheng H, Liu J, Shen C, Zhang C, Xu Y, Xiao C, Li X, Zhang J, Cao J. The short-term effects of air pollution on respiratory diseases and lung cancer mortality in Hefei: A time-series analysis. Respir Med. 2019:146:57-65.

\section{Publisher's Note}

Springer Nature remains neutral with regard to jurisdictional claims in published maps and institutional affiliations.

\section{Submit your manuscript to a SpringerOpen ${ }^{\circ}$ journal and benefit from:}

- Convenient online submission

- Rigorous peer review

- Open access: articles freely available online

- High visibility within the field

Retaining the copyright to your article

Submit your next manuscript at $\boldsymbol{\triangleright}$ springeropen.com 